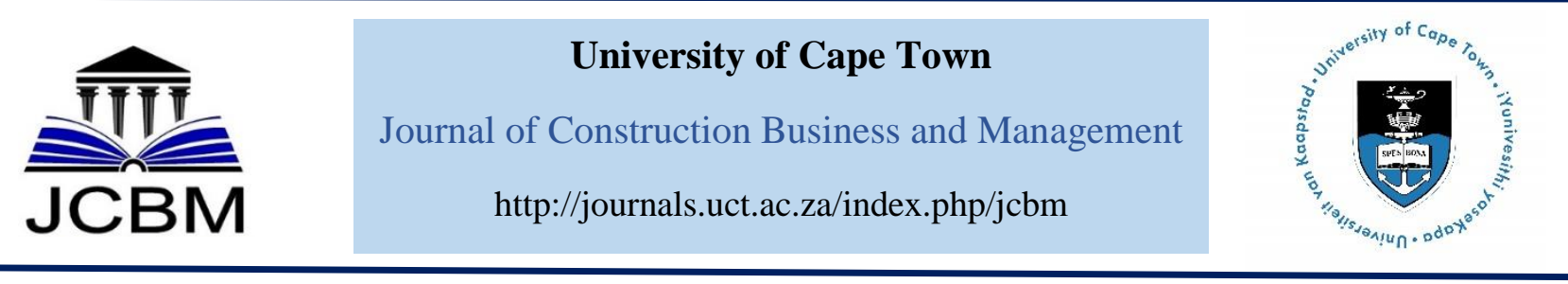

\title{
Groins or Not: Some environmental challenges to urban development on a Lagos coastal barrier island of Lekki Peninsula
}

\author{
J. N. Obiefuna ${ }^{1}$, A. Omojola ${ }^{2}$, O. Adeaga ${ }^{3}$, and N. Uduma-Olugu ${ }^{4}$ \\ Department of Architecture, University of Lagos, Nigeria $1,2,3,4$
}

Received 18 January 2017; received in revised form 25 February; accepted 28 February 2017

\begin{abstract}
Worldwide, barrier islands are usually sedimentary, dynamic and in high demand for urban development. Intense development negates their dynamics leading to risks necessitating protective measures like groins which tend to aggravate the problem. Suburban Lekki Peninsula on the south of Lagos metropolis is a large, long barrier island disposed largely to unplanned, accelerated growth since the first residential scheme in 1980 without consideration of its physical dynamics. This study, therefore, evaluated some risks confronting development from the dynamics of the Peninsula with the goal of demonstrating the use of low - budget online data for analysis of coastal hazards and risks. This entails the integration of remote sensing, GIS techniques to assess its characteristics and evaluate risks to development from some hazards inherent in island's physical processes as a typical barrier island on the Lagos coastline. Findings reveal that the area which was hardly built up in 1984 had grown to about $18 \%$ in 2014 with Eti-Osa LGA as the most developed at $68.4 \%$ and the most low-lying of the three comprising councils. Results further confirm the Peninsula as narrow in a few sections and generally low-lying with $37 \%$ between $0.5-3 \mathrm{~m}$ while $63 \%$ is between $3-5 \mathrm{~m}$ above mean sea level (MSL). Medium to maximum rates of beach erosion occur mainly in Eti-Osa LGA at about $22.75 \mathrm{~m} / \mathrm{yr}$ around Kuramo Waters, decreasing to $5.5 \mathrm{~m} / \mathrm{yr}$ around Goshen Estate. Projections on coastal erosion on the most erosive area in Eti-Osa LGA from 2013 reveal potential socio-economic impacts on road infrastructure and buildings as ranging from a minimum of N1.16billion to N139.42billion over the next 30 years at present level of development and values. The study concludes that the greatest risk from Barrier Island processes assessed is mainly in Eti-Osa LGA with Kuramo Waters area as the epicentre. Recommendations include the base flood elevation (BFE) and design flood elevation (DFE) to enhance the resilience of future developments. Comparative observations from the literature on the effect of groins on downdrift areas were further made to highlight new risks on the Peninsula.
\end{abstract}

Keywords: Barrier Island; Urban development; Hazard and risk evaluation; DEM; Storm surge flooding; Coastal erosion.

\section{Introduction}

\subsection{Background}

Coastal zones worldwide are acknowledged as areas of intense natural and anthropogenic processes, home to a large and expanding human population while at the same time experiencing environmental degradation (Asangwe, 2006; Population Reference Bureau - PRB, 2003). Coastlines generally are dynamic areas where three environmental zones of land, air and water converge. A striking feature of some of the world's coastlines and coastal areas are the fragile, sometimes thin accumulations of sand and vegetation that form the barrier island system along these coasts. These barrier islands which are usually sedimentary or depositional are separated from the mainland by estuaries, bays or lagoons. Unlike the stationary mainland landforms, Barrier islands naturally are unstable, eroding, migrating and rebuilding in response to winds, waves, tides, currents, sea level

\footnotetext{
${ }^{1}$ Corresponding Author. Tel: +234 8023150648 .

Email address: jerynus@yahoo.com

${ }^{2}$ Email address: demola_omojola@yahoo.com

${ }^{3}$ Email address: oadeaga@ unilag.edu.ng

${ }^{4}$ Email address: nnezi.udumaolugu@ gmail.com
} 
changes and other relentless ocean environment processes such as extreme episodic storm events (EESE's) (Feagin et al., 2010). Worldwide, barrier islands are in high demand for having become highly sought after locations for development and recreation. The attraction of ocean views and beaches has drawn lots of people to settle on or take vacations on barrier islands (Zhang \& Leatherman, 2011). For instance, in the United States with established formal planning for development, about $12 \%$ of all the barrier islands on Atlantic and Gulf coasts are completely urbanised while $36 \%$ are heavily developed (Stutz \& Pilkey, 2005).

Barrier islands which are known to exist in $10 \%$ of world's coastlines (Stutz \& Pilkey, 2011) are extremely fragile, dynamic, sometimes transitory, restless and relatively young coastal geomorphic features. They are usually formed in response to these common factors namely: large sand supply, gentle sloping mainland coastal plain, and sufficient wave energy to move sand around, rising sea level and a low to the intermediate tidal range (Bush et al., 2004). Thus, they are constantly maintained and remade by the complex interaction of rivers, sediment supply, sea-level change, ocean currents, wave energy and the wind (Western Carolina University - WCU, 2005; Jack, 2003). Looking at the total length of barrier island shoreline, the United States with the highest of 405 islands has about $24 \%$ of the world's barrier islands while Madagascar, Colombia and Nigeria each has 3\% of the global length of barrier islands (Stutz \& Pilkey, 2011). Of its share of the global length of barrier islands, Nigeria's $800 \mathrm{~km}$ of Atlantic coastline is mostly composed of beach ridge barrier islands (Ibe, 1988). These include the Barrier - Lagoon complex of the Lagos coastline from the Benin Republic border for $200 \mathrm{~km}$ to the Transgressive Mud Beach east of it. This is followed by a chain of 20 or more beach ridge barriers or deltaic barrier islands (Stutz \& Pilkey, 2011), extending for about $500 \mathrm{~km}$ on the rim of Niger Delta. Next to this and extending for $85 \mathrm{~km}$ from Imo River to Cross River estuary is the Strand Coast which for the most part is rimmed by a barrier island chain. Of these barriers, the most generally developed with human settlements are in the Lagos barriers (Ibe, 1988).

The Lagos coastline itself is rimmed in its entirety by barrier islands. These include the Badagry Island/Lighthouse Beach backed by Badagry Creek and Lighthouse Creek, Victoria Island backed by Five Cowrie Creek and Lekki Peninsula which is backed by Five Cowrie Creek, Lagos and Lekki Lagoons. Of these, Victoria Island which had experienced phenomenal erosion and lost over $1.5 \mathrm{~km}$ of land near the eastern breakwater is the most developed and constitutes one of the important commercial and residential areas of the country (Nwilo, 1997).

Some research works have summarised the inherent dangers or challenges confronting development on coasts and barrier islands generally and particularly in the United States (Bush et al. 1996; Stutz \& Pilkey, 2005; WCU, 2005; Feagin et al. 2010 and Taylor, 2014). For barrier islands, these challenges include their sandy nature, wind, waves and currents, low elevation and attendant flooding, their unstable and migratory nature, storms and storm surge flooding, coastal erosion and consequent placement of coastal defence structures to check eroding shorelines. Cumulatively, these works concluded that urban development is a major driver of environmental degradation and habitat loss on barrier islands as these developments with stabilisation projects initiated hazardous conditions, wetland losses along with sediment and geomorphic changes. Further, they observed that in the past few decades, despite escalating disaster-related losses and environmental risks of living on these islands, barrier island communities in the United States continue to grow and rebuild even after major storm disasters.

Rapid urbanisation therefore in a generally low-lying Lagos metropolis has led to the unplanned and extensive reclamation of wetlands, encroachment on natural drainage channels and unrestrained deforestation to provide land for rapid urban expansion (Abegunde, 1988). Lekki Peninsula sub-region which is on the southern flank of Lagos is part of the metropolis experiencing rapid urbanisation in recent years. Although given the name 'Lekki Peninsula', it is an island (LASG, 1980). Being a part of the Barrier-Lagoon complex (Awosika et al., 2000; Awosika et al., 1993a; Ibe, 1988; Nwilo, 1997), Lekki Peninsula is principally a large barrier island. Having an appreciable store of fragile, undeveloped land close to the highly developed high-brow and previously very erosive Victoria Island (a barrier island also), this has predisposed it to be one of the most dynamic growth areas. Since the Lekki Scheme I in 1980's by the State Government, development has accelerated including residential schemes, Lekki Free Trade Zone Phase 1 (LFTZ) and infrastructure master plan (Fig. 1.1a, b, c) and has outpaced physical planning until recently. Missing in these development activities and in the literature is the consideration of barrier island dynamics and hazards/risks from its physical processes such as erosion, devastation and flooding as shown in Plate1.1 a - e) and exemplified from barrier islands of Long Island, New York, Miami Beach, Florida, on Victoria Island and on the Peninsula itself. Appropriate planning and development which recognises the dynamic characteristics of such island and others like it as well as human needs should guide the location of development activities (Taylor, 2014) to enhance livability.

Against this background, this study sought to evaluate how existing and continuing development are at risk from the physical processes of Lekki Peninsula as a case study and how this information could be used to safeguard existing development and guide future ones on it and other developing Lagos barriers. In advanced countries, costly imageries, sophisticated analytical techniques and historical shoreline data are in use for coastal hazard evaluation. For a developing country like Nigeria which lacks these tools and funds are usually limited (Bush et al., 1999), a viable low - cost alternative approach for coastal risk evaluation becomes desirable. In this regard, the study focused on the use of free online imageries and data to augment baseline data for a low-budget evaluation of proxies of coastal processes or geo-indicators and their inherent hazards. Among the objectives are the assessment of the island physical characteristics or geoindicators, the evaluation of the hazards of these physical processes and the risks they pose to urban development on the island. These are what are reported in this paper. 

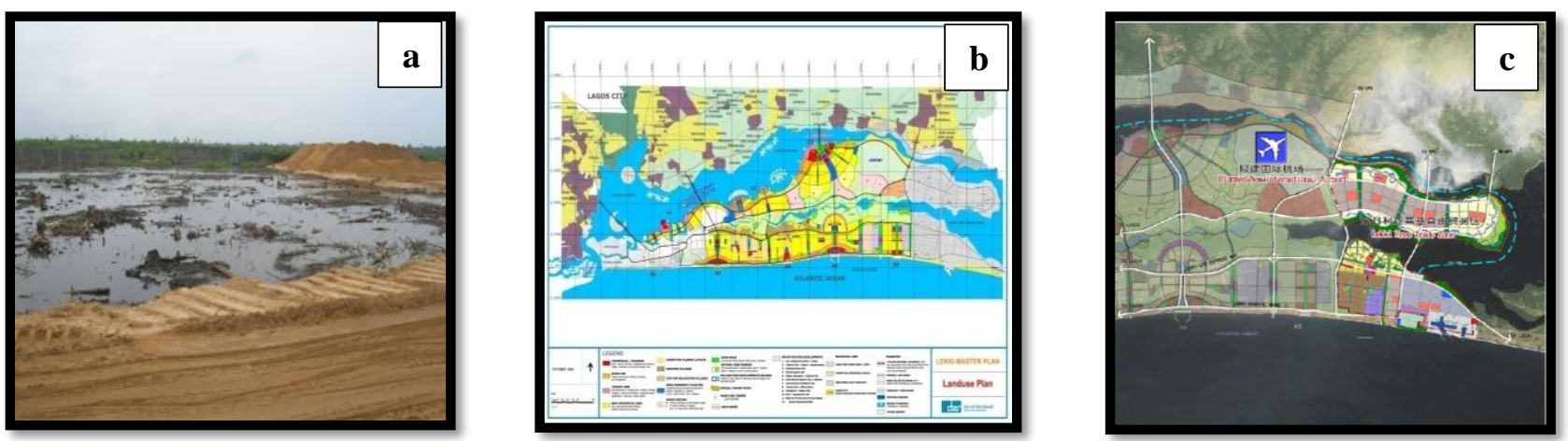

Figure 1.1a-c: a) Current development and wetland reclamation in Lekki Peninsula; b) Lekki Master Plan proposal (source: Dar al-Handasah, 2009 and c) Lekki Free Trade Zone (Source: China- Nigeria ETCZ, 2009).

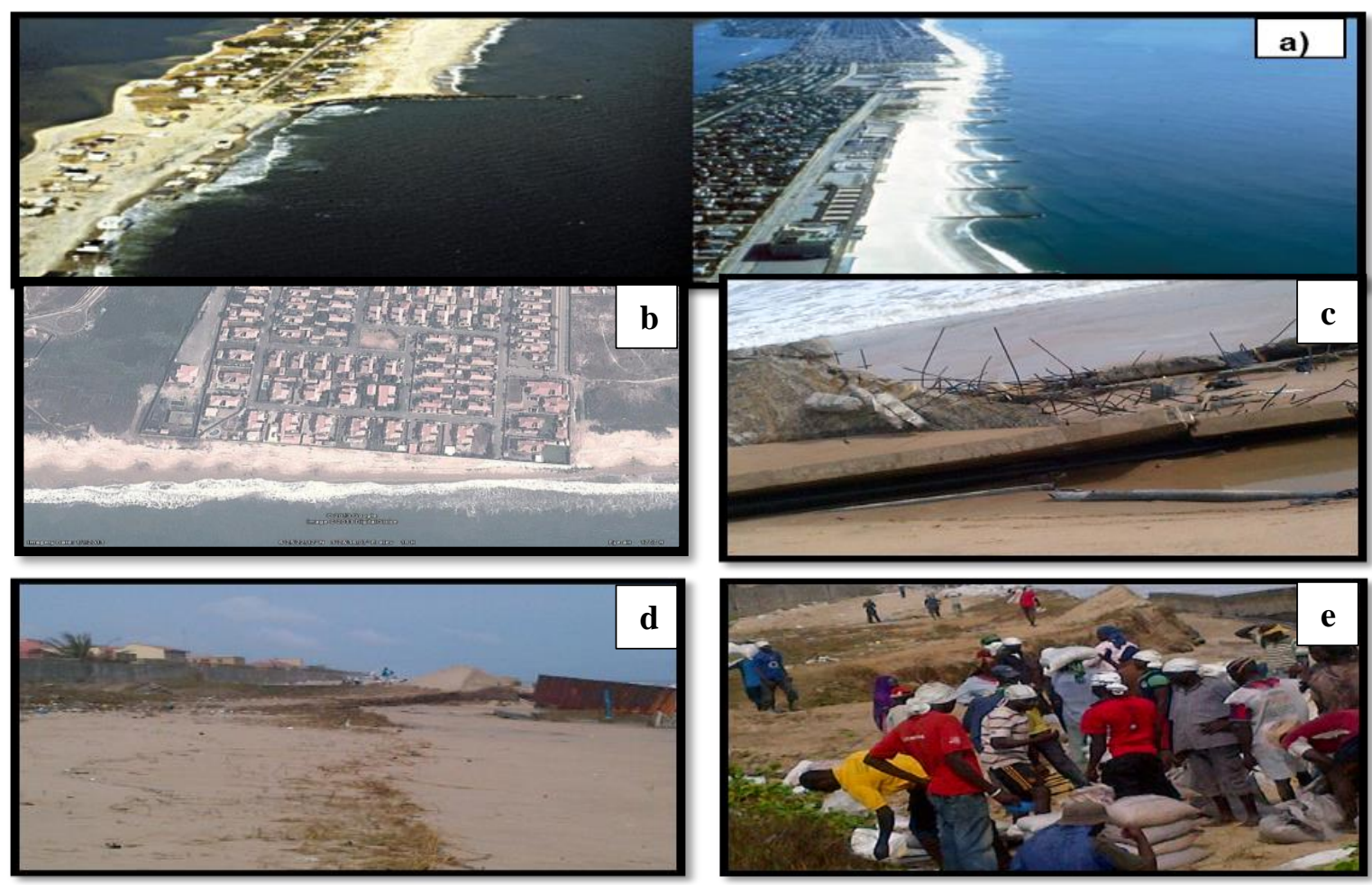

Plate 1.1a-e: Beach erosion and devastation on barrier island coastlines. a) Beach Erosion and deposition are regular features of barrier island coastlines. Groins interrupt the natural sand flow and can exacerbate erosion on downdrift side of the coastline. (Source: Tanski, 2007). b) 2013 imagery showing erosion around Goshen Beach Estate, Lekki (source: Google Earth, 2013). c) Goshen Beach Estate - remains of shallow-depth retaining wall after the ocean surge of 24-8-12, d \& eGoshen Beach Estate - devastation from the surge of 24-8-12 \& workers readying sandbags as barriers to ocean surge.

\subsection{Characteristics of barrier islands \& geo-indicators}

As their name implies, barrier islands are usually narrow and sometimes elongated, shore-parallel sandy islands placed by nature in front to protect the mainland area from direct ocean waves and storms (Fig. 1.2a, b). Having been formed by the combined action of sand deposition, winds, wave action, tides, currents, longshore drift, sea level rise and fall, the morphology of barrier islands is very dynamic, changing constantly in response to the self-same coastal processes responsible for their formation (Zhang \& Leatherman, 2011; Feagin et al., 2010; Bush et al., 2004 ; Jack,2003). As dynamic sand accumulations, they are endowed with two turbulent coasts, the ocean side and lagoon side (Taylor, 2014). The ocean side is prone to strong winds, waves, storms or surges, longshore and rip currents, coastline erosion and/or deposition as well as sea level variation. On the lagoon side are usually the tidal salt marshes and wetlands. Between the beach and the lagoon side in the higher latitudes are the primary dune, the secondary dune, the back dune and the flat zone, the flats being the best location for urban development as prescribed by Mcharg (1971). The primary dune serves as the major defence against the sea and therefore intolerant of breaching with perpendicular roads or building development (Mcharg, 1971). Unlike in the higher latitudes where onshore winds play a significant role in dune formation, their role in translating beach sediments inland on the humid tropical barriers is an unsettled issue, hence beach dune development in the low latitudes are not 
as prominent. Thus the Nigerian coastline including Lekki Peninsula is characterised by flat beaches (Ibe, 1988). Changes in sea level, wave regime, sediment supply, storm or storm surge frequency coupled with the construction of shore protection structures (groins, seawalls, bulkheads and others) influence the behaviour of barrier islands as geomorphic features. Furthermore, conventional urban development of buildings and infrastructure involves rigid structures whose rigidity conflicts with the physical dynamics of barrier islands. Consequently, the increasing pressure on the dynamic barrier island landscapes and coupled ecosystems to become rigid as human-dominated features make them unable to render the same ecosystem services and resilience dynamics as the original settings (Stutz \& Pilkey, 2005). Stated differently, urban development on barrier islands counteracts their dynamics creating problems.

Geo-indicators or island characteristics (Bush et al. 1999) which includes island width, elevation, vegetation density, beach character and configuration, shoreline stability, or rate of shoreline change and storm frequency (or heavy rainfall and storm surge frequency as is applicable here), barrier island interior geomorphology and wind can be used to estimate islands geomorphic carrying capacity. This is because island width gives a

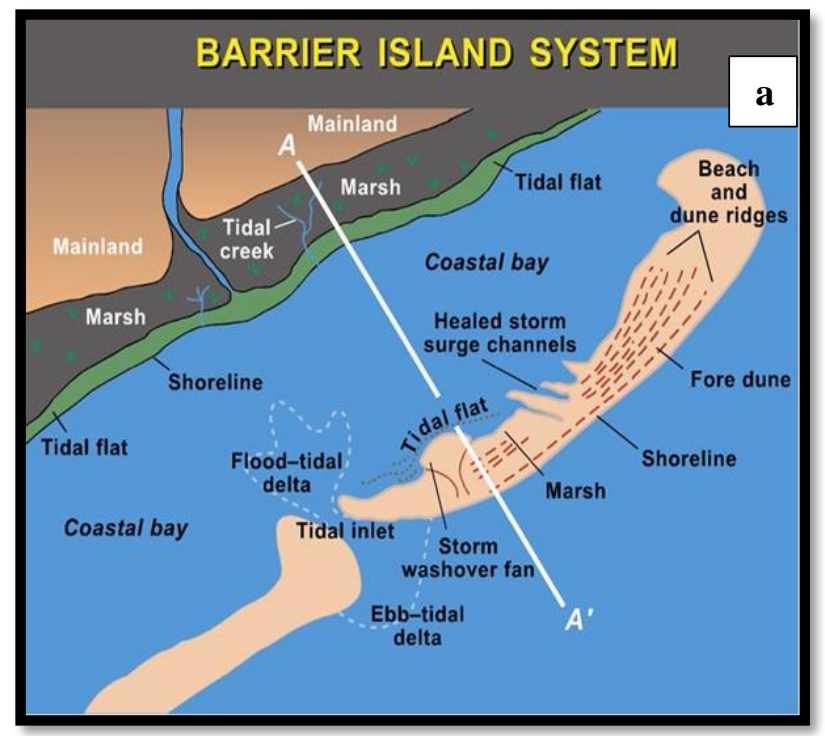

measure of available space or proximity to dynamic processes of beach erosion and waves. The rate of shoreline change or erosion along with island width is the most important measure of the long-term stability of the island in terms of sea level and sediment supply. Both enable a prediction of the 'expected lifetime' of urban development or activity on the island. Storms or heavy rainfall and storm surge are responsible for flooding and risk to human development while elevation is a measure of an island's vulnerability to flooding. Bush et al. (1999) suggest that geo-indicators provide a low-cost tool for rapid assessment of coastal hazard risk potentials either for environmental monitoring or coastal assessment. These indicators are proxies expressing the short - term coastal dynamics and representing all the elements on which the coastal processes depend. They suggest that in developing countries where funds are limited and historical shoreline position data is often lacking, geoindicators can provide simple, qualitative tools for rapid assessment of coastal hazards and risk potential. Thus, geo - indicators can be used to evaluate risk from coastal hazards such as coastal erosion, storm surge flooding, dune loss, overwash and human induced problems, loss of critical systems, increased erosion and loss of sand supply.

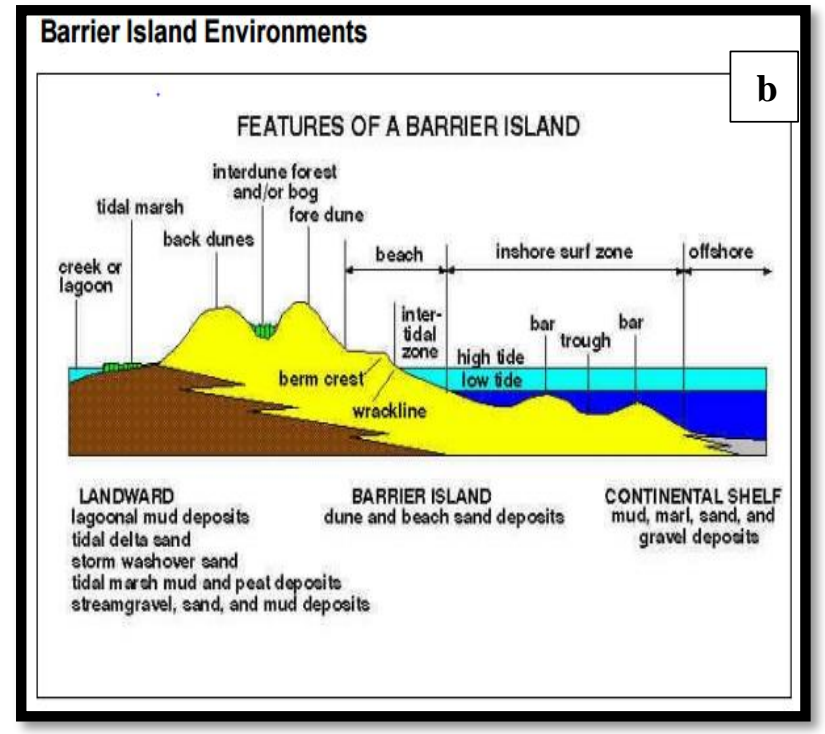

Figure 1.2 a-b: a) Typical barrier island system; b) Typical barrier island cross section - ocean to the lagoon or bay. (Source: https://sharkresearch.rsmas.miami.edu/assets/pdfs/learning-tools/).

\subsection{Some effects of development on barrier islands}

To situate and appreciate some of the consequences of development on barrier islands worldwide, two examples, one from Maryland, USA and the other, Victoria Islands Lagos serve to illustrate those effects. As argued by Mcharg (1971), waves normally approach the beach from an angle while water runs over the sand and recedes at right angles to the shore. By this, sand carried by the receding waves is transported through littoral drift down drift of its origin. Sand, therefore, continues to be moved in one direction and on the New Jersey Atlantic seashore, for example, this direction is southwards. Thus, groins emplaced perpendicular to the coast causes accretion/deposition on the upper end and erosion on the lower end while the northern tips of barrier islands here tend to be eroded with the southernmost tips elongated with sand deposition (Mcharg, 1971). In this light, the building of rock jetties stabilised Ocean City Inlet, Maryland but they altered the normal north - to - south sand transport by longshore currents and initiated accelerated erosion and deposition. This resulted in sand build up behind the north jetty while the sand below the south jetty was quickly eroded. This accelerated erosion has shifted Assateague Island south of the inlet about $0.8 \mathrm{~km}$ inland (Fig. $1.3 \mathrm{a}-\mathrm{c}$ ). The other example of 
development effects is from Victoria Island. The construction of the almost perpendicular breakwaters from 1908 to 1912 at the entrance of Lagos harbour initiated a phenomenal beach erosion of $25-30 \mathrm{~m} / \mathrm{yr}$. east of the eastern mole in Victoria Island (Ibe, 1988). This erosion as determined through aerial photographs saw the shoreline recede by about $2 \mathrm{~km}$ threatening the heavy development on the frontage Ahmadu Bello Way. This was while progressive accretion was occurring on Lighthouse beach, behind the west mole (Fig.1.4a, b). Although this is currently being tamed by the construction of Eko Atlantic City project, obvious indications are that this phenomenon may have shifted further eastwards to the Peninsula.
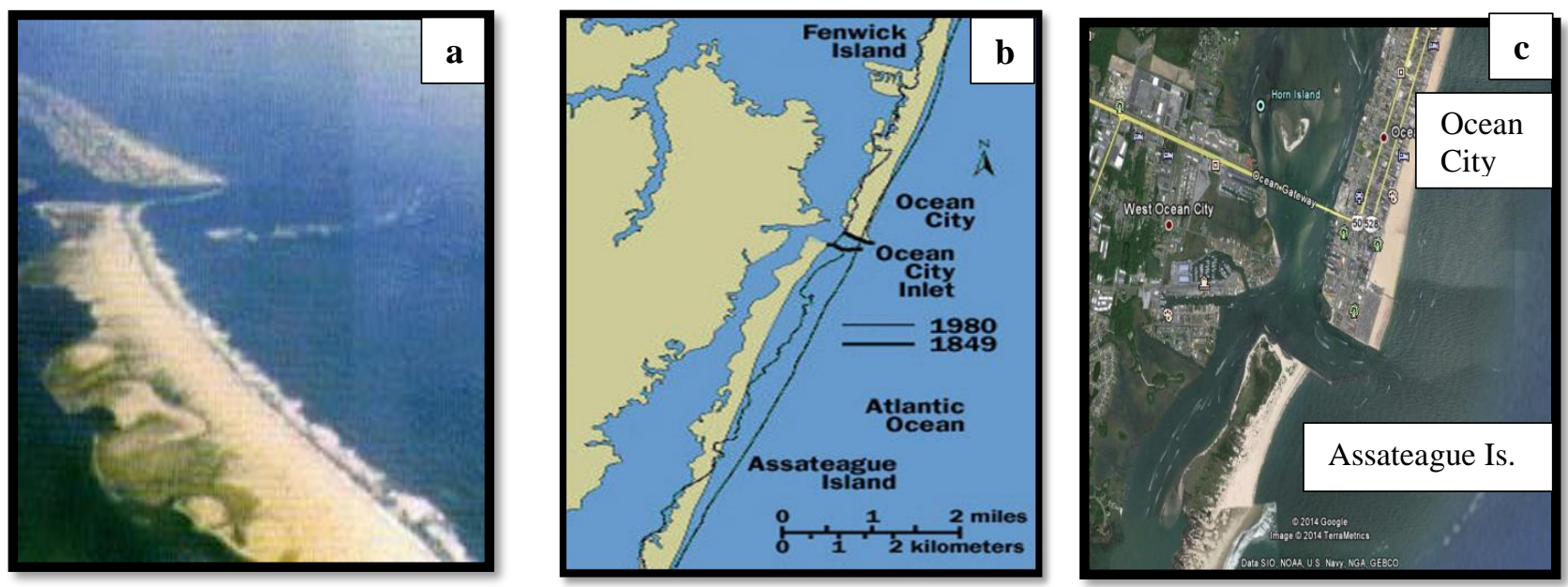

Figure 1.3 a-c: Changes in Assateague Island, Maryland (USA) as a result of accelerated erosion from the man-made rock jetties of Ocean City Inlet. a) Photo of the inlet; b) Map of the area with outline showing the position of the island in 1849 and in 1980; c) Imagery of the same island in 2010 (Sources: Freudenrich, 2014, http://science.howstuffworks.com, 2014. Google Earth, of 7-4-2010).

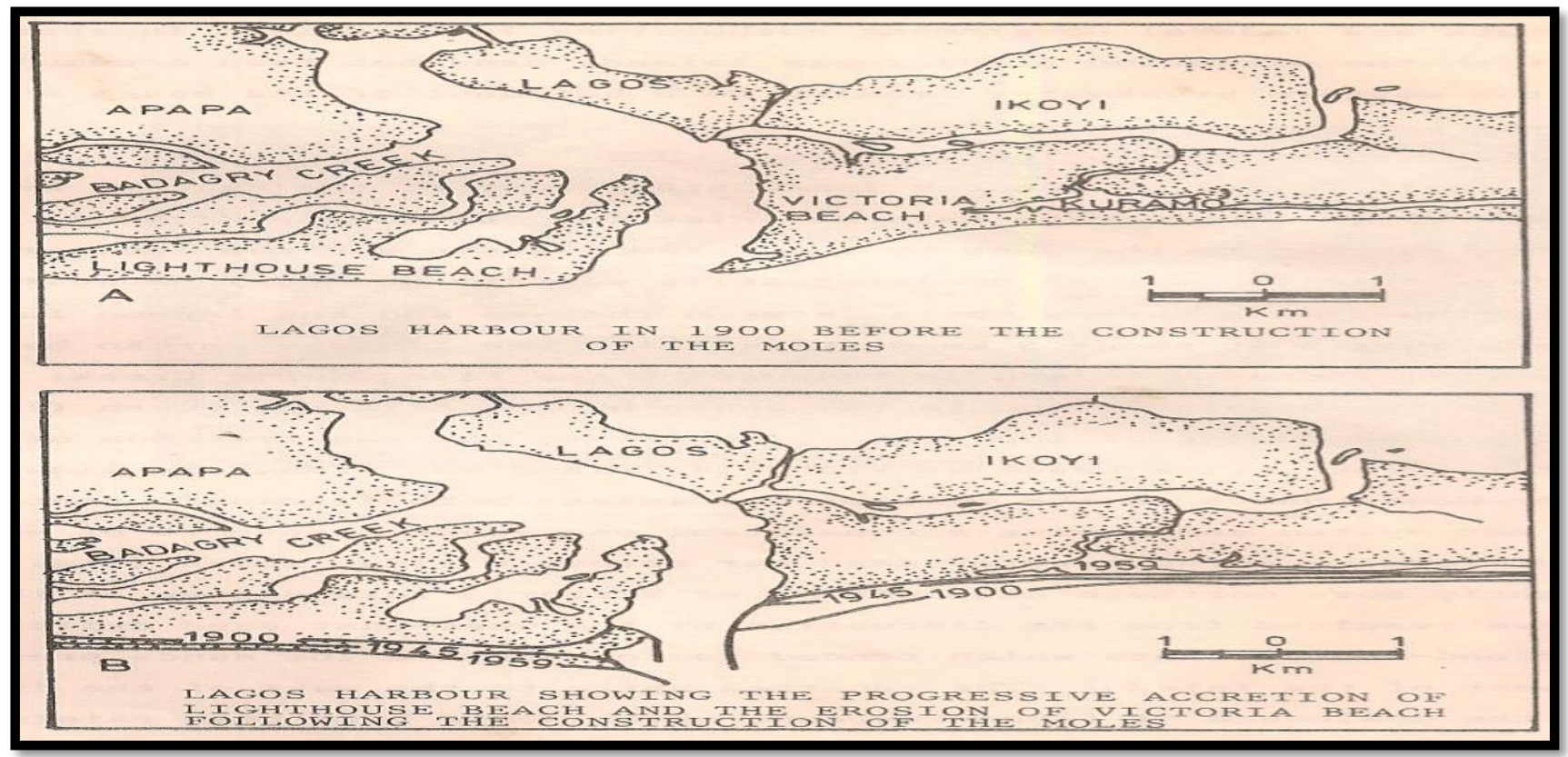

Figure 1.4: The Lagos coastline showing V.I. and entrance to Lagos harbour before (A) and after (B) the construction of the breakwaters (Source: Ibe, 1988).

\section{Methods}

\section{$2.1 \quad$ The study area}

The study is conducted on the Lekki Peninsula, a rapidly urbanising area south-east of Lagos metropolis and one of the barriers on the Lagos coastline (Fig. 2.1). It is located to the east of Victoria Island, bounded on the west by
Igbosere Creek which connects Kuramo Waters to FiveCowrie Creek. On the north, it is bounded by the Lagos and Lekki Lagoons; on the east by Ogun State. On the south, it is bordered by the Bight of Benin/Atlantic Ocean. It covers an area of about 98,000 hectares or $980 \mathrm{~km} 2$, extending eastwards for a distance of about 100 kilometres from its western boundary. The location is at about Latitude $6^{\circ} 22^{\prime} \mathrm{N}$ and $6^{\circ} 37^{\prime} 10^{\prime \prime} \mathrm{N}$ and Longitude $3^{\circ}$ 
$25^{\prime} 50^{\prime \prime}$ and $4^{0} 21^{\prime} 20^{\prime \prime E}$. The climate of the area as experienced in the Lagos metropolis is influenced by two air masses namely: the tropical maritime and tropical continental air masses. The former is wet and originates from the Atlantic Ocean while the latter, a warm, dry and dusty air, originates from the Sahara Desert. Two seasons are generally experienced in the area namely, rainy season (April - October) and dry season (November - March). Based on the 20 local government areas of the state, the Peninsula is composed mainly of Etiosa, Ibeju/Lekki LGA's and a portion of Epe LGA.

Geomorphologically, Ibe (1988) suggests the barriers on the Lagos coastline of which Lekki Peninsula is one are part of the low-lying Barrier-Lagoon complex which extends from the Nigeria/Benin border eastwards for about $200 \mathrm{~km}$. The morphology of the complex was determined by the coastal dynamics, drainage and four interrelated coastal processes (Ibe, 1988). First, characterised by erosive beaches, there is the absence of 'exoreic' rivers which would have replenished from hinterland sand lost from long shore current action. This according to him explains the absence of spits and barriers developing presently. Secondly, there is a very active west to east longshore current. Thirdly, the complex has a narrow, steep continental shelf of about $30 \mathrm{~km}$ wide and which is indented by gullies and submarine canyons including the Avon Canyon $\left(6^{\circ} 10^{\prime} \mathrm{N}\right.$ and $\left.3^{\circ} 55^{\prime} \mathrm{E}\right)$ and Mahin Canyon further east. This narrow continental shelf enables waves to reach the shore at higher heights and promotes the loss of near shore sediments to the gullies and canyons. Lastly, the intensity of wave action is high along the beaches due to the influence of the prevailing south-westerly winds. Also, Ibe (1988) notes that the Lekki Peninsula barrier island varies in width from $1 / 2 \mathrm{~km}$ to $21 \mathrm{~km}$ and is generally aligned parallel to the Atlantic coast. The barrier beaches of the Lagos coastline have an average altitude of $0.75-5 \mathrm{~m}$ above sea level (Abegunde, 1988). The Peninsula comprises of five geomorphologic sub-units namely: the abandoned beach ridge complex; the coastal creeks and lagoons; the swamp flats; the forested river floodplain and the Active barrier beach complex (Adepelumi, 2008).

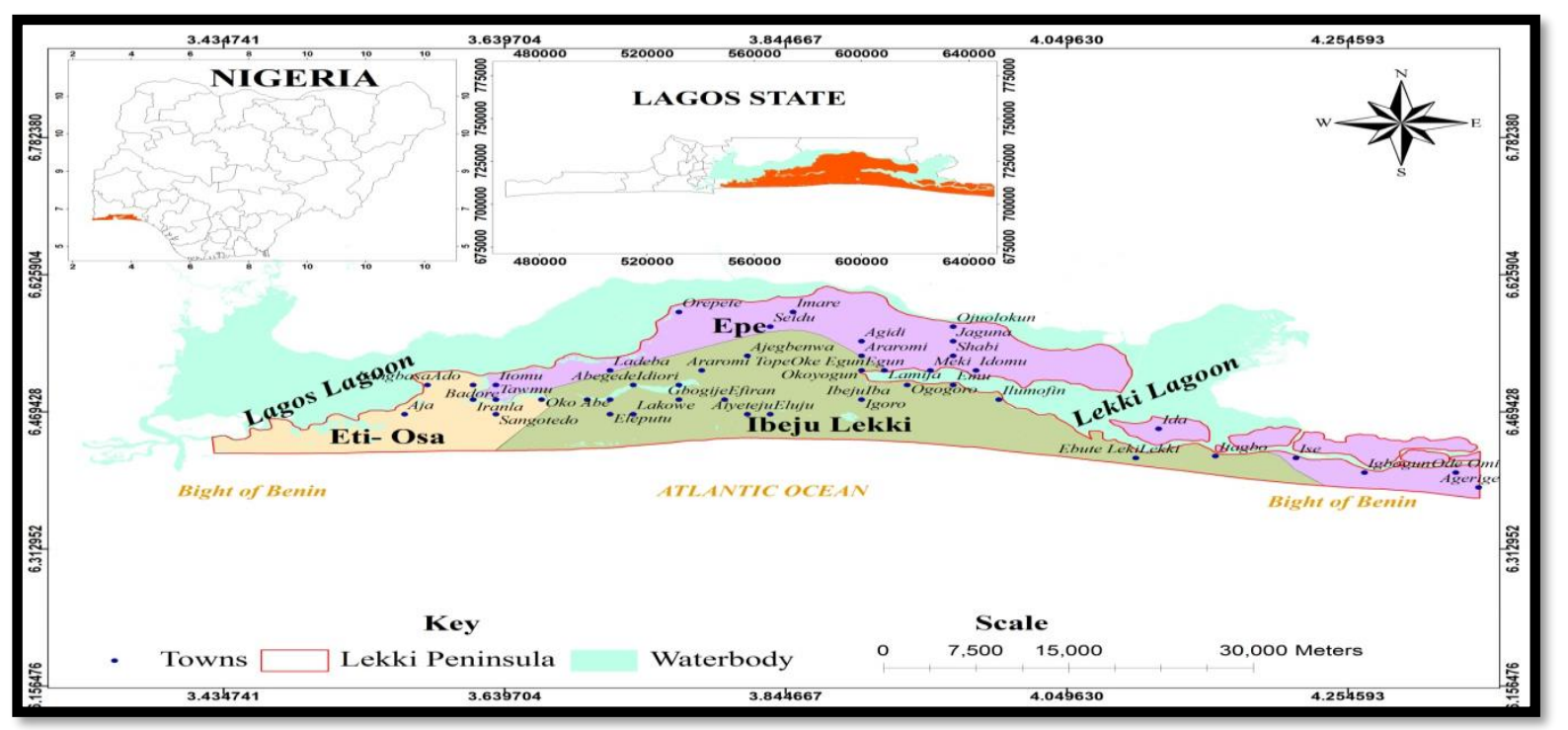

Figure 2.1: Lekki Peninsula and the LGAs'

\subsection{Data acquisition \& analysis}

The data utilised for the study include baseline data, those on geo-indicators or island characteristics, GPS/geodetic control data as well as ancillary data. Baseline data was acquired using OSGOF 1:25,000 topographic maps of 1984/85 of Lagos NE1; Abigi NE1, NW1\&2; Ibeju NE1\&2, NW1\&2; Ijebu-Ife SW3 and Ijebu-Ode SW4 sheets. These maps were scanned, digitised head-up, edge-matched and edited using AutoDesk Raster Design software. Geo-referencing of the digitised maps to UTM zone 31 was in ArcGIS with selected GPS control points extracted from Lagos State Geodetic Controls for the State's 'Enterprise Geographic Information System, LAGIS'. This was imported into ArcGIS 10 for all subsequent analysis. The indicators of island morphology extracted were island width, elevation and rate of shoreline erosion or recession. Island width was measured on three north-south transects corresponding to the narrowest segments in the west and east as well as on the larger portion in the middle of the island on the georeferenced baseline map of the island of 1984/85. The western transect which later turned out to be in the most erosive segment of the island was re-measured on overlaid and geo-referenced Google Earth high resolution imageries of December 2001 and that of December 2012/January 2013. For the extraction of elevation, online, freely available CGIAR - CSI 90m SRTM digital elevation model, DEM of 2000 (WGS 84, version 4.1) was downloaded from www.cgiar-csi.org/data/srtm-90mdigital-elevation-database-v4.1.v and classified. The positional accuracy between the WGS 84 datum and the Nigerian datum (Minna datum) was assessed to ascertain the need for transformation but showed a coincidence of coordinates of both datum and the absolute height error of SRTM DEM for Lagos area was about +/-0.0904m. With this elevation data, drainage network and drainage basins or the lack thereof were generated using Arc Hydro tools in Arc Hydro Geoprocessing Tools version 2.0. Beach recession or coastal erosion was analysed on the Atlantic 
coastline by overlaying the geo-referenced Google imageries of December 2001 and December 2012/January 2013 and measuring to the wet/dry lines on random UTM coordinates on similar images from the southern coastline of Lagos Lagoon and Five Cowrie Creek. A minor displacement noticed between corresponding images was assumed not to invalidate the results as they are taken as qualitative indicators, not absolutes as suggested by Bush et al. (1999).

Evaluation of the potential risk to development on the island was performed by intersecting the elevation data with planar GIS or 'bathtub fill' water levels (Van deSande, 2012; Poulter\& Halpin, 2008; Bates et al., 2005) of 0.5 - above $4.1 \mathrm{~m}$ from datum to derive a flood hazard potential for both pluvial and marine flooding. To evaluate coastal erosion risks, the minimum $(5.42 \mathrm{~m})$, moderate $(10.25 \mathrm{~m})$ and maximum $(22.75 \mathrm{~m})$ erosion rates were radiated inwards from the coastline in 10-year intervals for 30 years of the most erosive area in Eti-Osa LGA to establish the extent potentially lost if the erosion rate is unperturbed. Image mensuration (Jensen, 2007) and valuation (Otegbulu, 2013) were done to estimate socio/economic impact on buildings and road assets in Eti-Osa LGA.

\section{Findings}

A separate evaluation of land cover change indicates that from $0.5 \%$ in 1984, urban development or built up area had grown to $18 \%$ in the Peninsula in 2014 with Eti-Osa LGA being the most developed at about $68 \%$ and IbejuLekki LGA at 7\% in 2014. Transects on 1984/85 map show that island width was narrowest in the west (Maroko area, Meridian $3.44270 \mathrm{E}$ ) at $1.76 \mathrm{~km}$, in the east at $1.93 \mathrm{~km}$ and in the middle of the island at $19.1 \mathrm{~km}$ (Fig. 3.1). This transect on Maroko area on Google imagery between 2001 and 2013 shows that island width has reduced to $1.52 \mathrm{~km}$ by 2013 due to coastal erosion. Elevation distribution (Fig. $3.2 \&$ Table 3.1) confirms the Peninsula as mainly low-lying with $37 \%$ at $0.5-3 \mathrm{~m}$ and $63 \%$ at $3-$ $5 \mathrm{~m}$ above m.s.l. Eti-Osa LGA, the smallest of the area councils, is the most low-lying (Fig.3.3) with $0.5-3 \mathrm{~m}$ $(78 \%)$ dominant while its Atlantic coastlines are mostly at $0.5-1.5 \mathrm{~m}$. The heights of $3-4 \mathrm{~m}$ dominate in Epe $(62.8 \%)$ and Ibeju Lekki (59\%). Extreme flood hazard potential on planar water levels (0.51-2m; Fig.3.4) was mainly in EtiOsa LGA. Results of drainage analysis show the existence of minimal drainage basins over the Peninsula (Fig. 3.5). Results on beach erosion (Table 3.2) also show that the maximum rate of erosion occurs mainly in Eti-Osa LGA at about $22.75 \mathrm{~m}$ yr-1 around Kuramo Waters decreasing to $5.5 \mathrm{~m}$ yr-1 around Goshen Estate and minimal in the east (Fig. 3.6). Kuramo Waters, a formerly enclosed water body was observed to have been breached by the Atlantic Ocean in 2012. Similarly, Goshen Estate's fence was measured at $14.80 \mathrm{~m}$ on Google Earth imagery of $17 / 4 / 2012$ but had reduced to $11.21 \mathrm{~m}$ from wet/dry or high water line in 2013 after the ocean surge of July 2012 (Plates 3.1a, b). If any doubt existed on the veracity of the erosion results, a subsequent Google Earth imagery of 5/3/2014 (Plate 3.2) clearly showed new groins constructed in this vicinity as apparent confirmation of extant serious erosion.

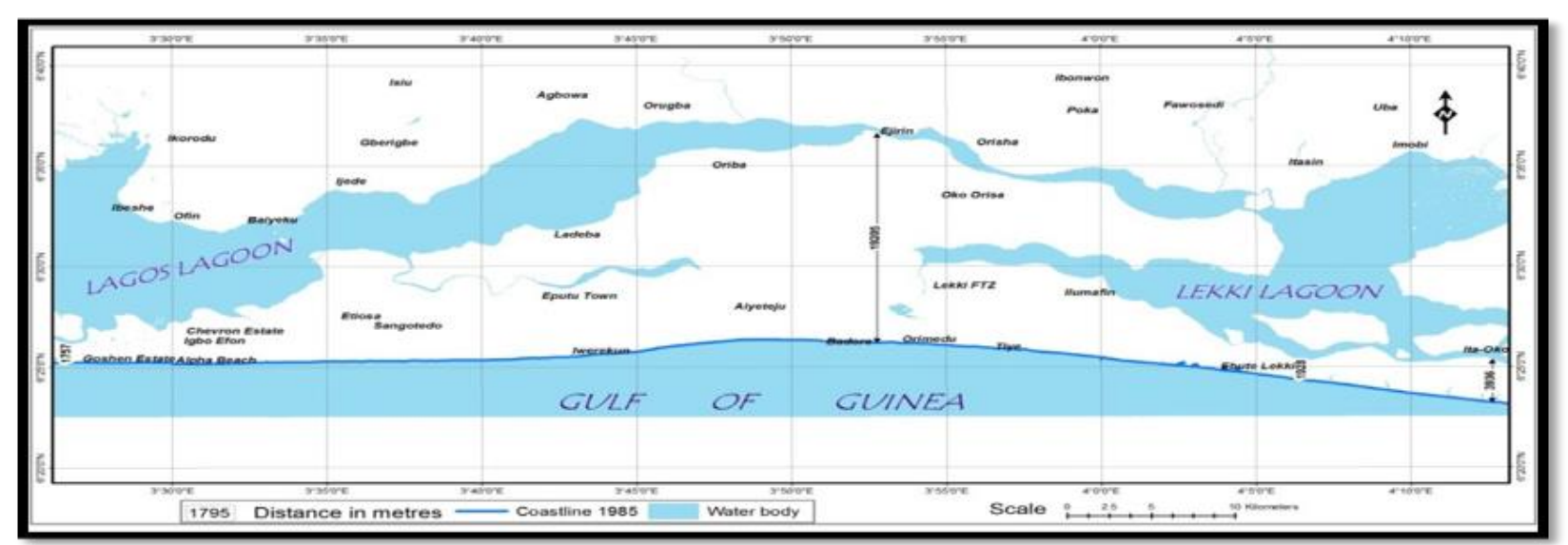

Figure 3.1: Transects of Island width in 1984/85.

Table 3.1: Spatial Distribution of elevation \& percentages in LGA's (Derived from SRTM data of 2000).

\begin{tabular}{|c|c|c|c|c|c|c|}
\hline \multirow[b]{2}{*}{ Elevation (m) } & \multicolumn{2}{|c|}{ Eti-Osa LGA } & \multicolumn{2}{|c|}{ Ibeju-Lekki LGA } & \multicolumn{2}{|c|}{ Epe LGA } \\
\hline & Area C & $\mathrm{d}\left(\mathrm{km}^{2}\right)$ & Area C & $d\left(\mathrm{~km}^{2}\right)$ & Area ( & $\left(\mathrm{km}^{2}\right)$ \\
\hline $0-0.5$ & 0.00 & $0.0 \%$ & 0.06 & $0.0 \%$ & 0.00 & $0.0 \%$ \\
\hline $0.5-1$ & 1.60 & $1.1 \%$ & 1.41 & $0.3 \%$ & 0.71 & $0.2 \%$ \\
\hline $1-1.5$ & 18.98 & $13.3 \%$ & 3.38 & $0.7 \%$ & 4.91 & $1.5 \%$ \\
\hline $1.5-2$ & 27.09 & $19.0 \%$ & 9.89 & $2.1 \%$ & 14.28 & $4.3 \%$ \\
\hline $2.0-3.0$ & 64.63 & $45.3 \%$ & 122.11 & $26.1 \%$ & 77.62 & $23.1 \%$ \\
\hline $3.0-4.0$ & 27.48 & $19.2 \%$ & 276.79 & $59.2 \%$ & 210.54 & $62.8 \%$ \\
\hline $4.0-5.0$ & 3.03 & $2.1 \%$ & 53.64 & $11.5 \%$ & 27.23 & $8.1 \%$ \\
\hline $5.0-6.0$ & 0.00 & $0.0 \%$ & 0.00 & $0.0 \%$ & 0.23 & $0.1 \%$ \\
\hline Total & 142.81 & & 467.28 & & 335.52 & \\
\hline
\end{tabular}




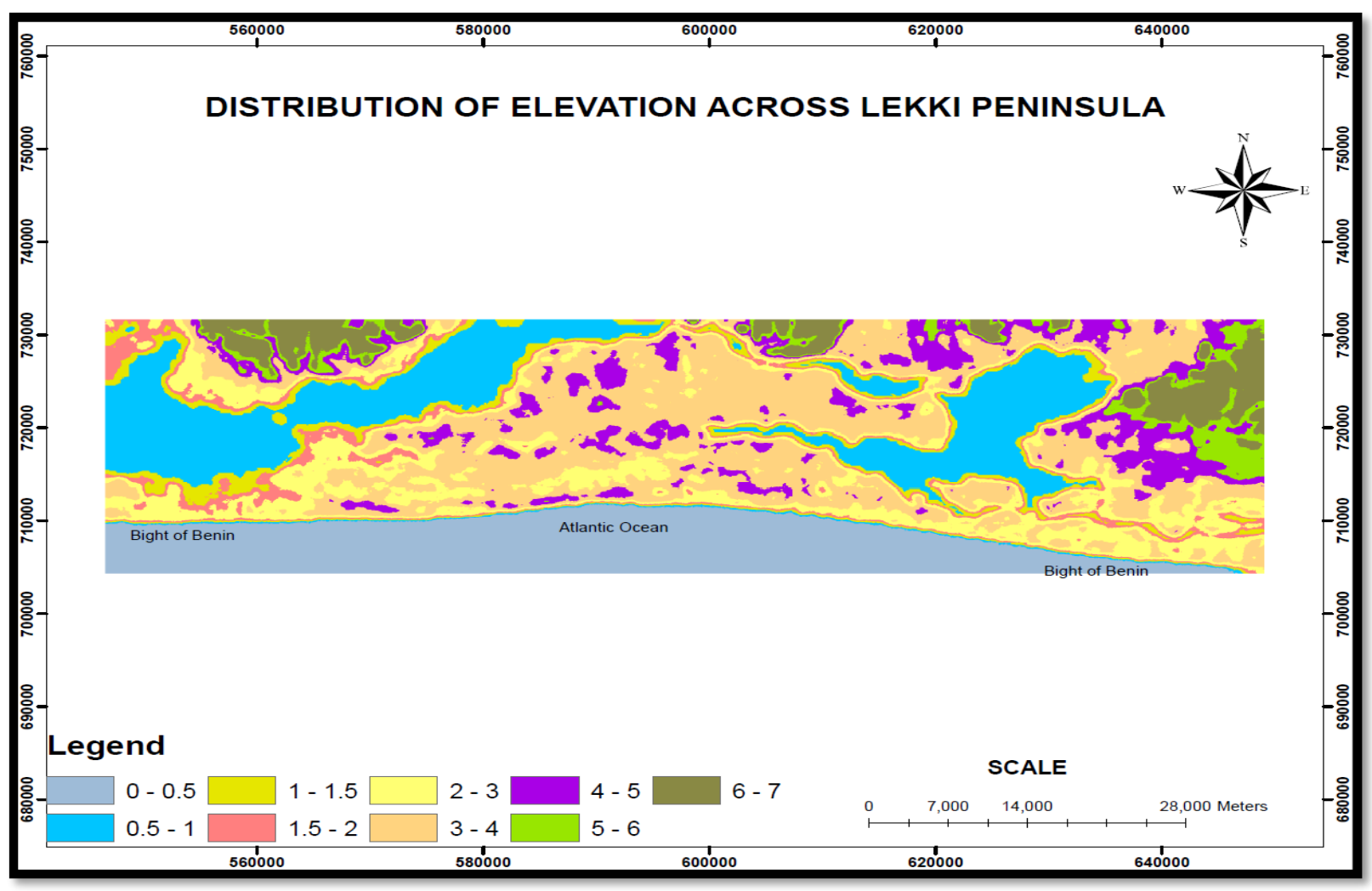

Figure 3.2: The distribution of elevation on Lekki Peninsula (Source: SRTM DEM data).

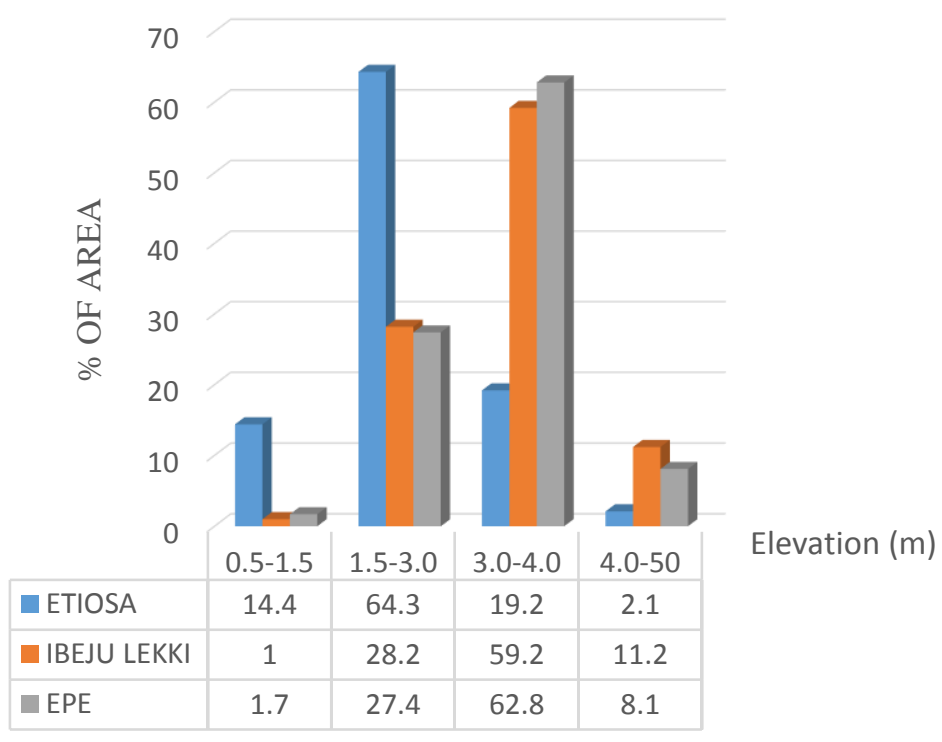

Figure 3.3: Histogram plot of elevations across LGA's. 


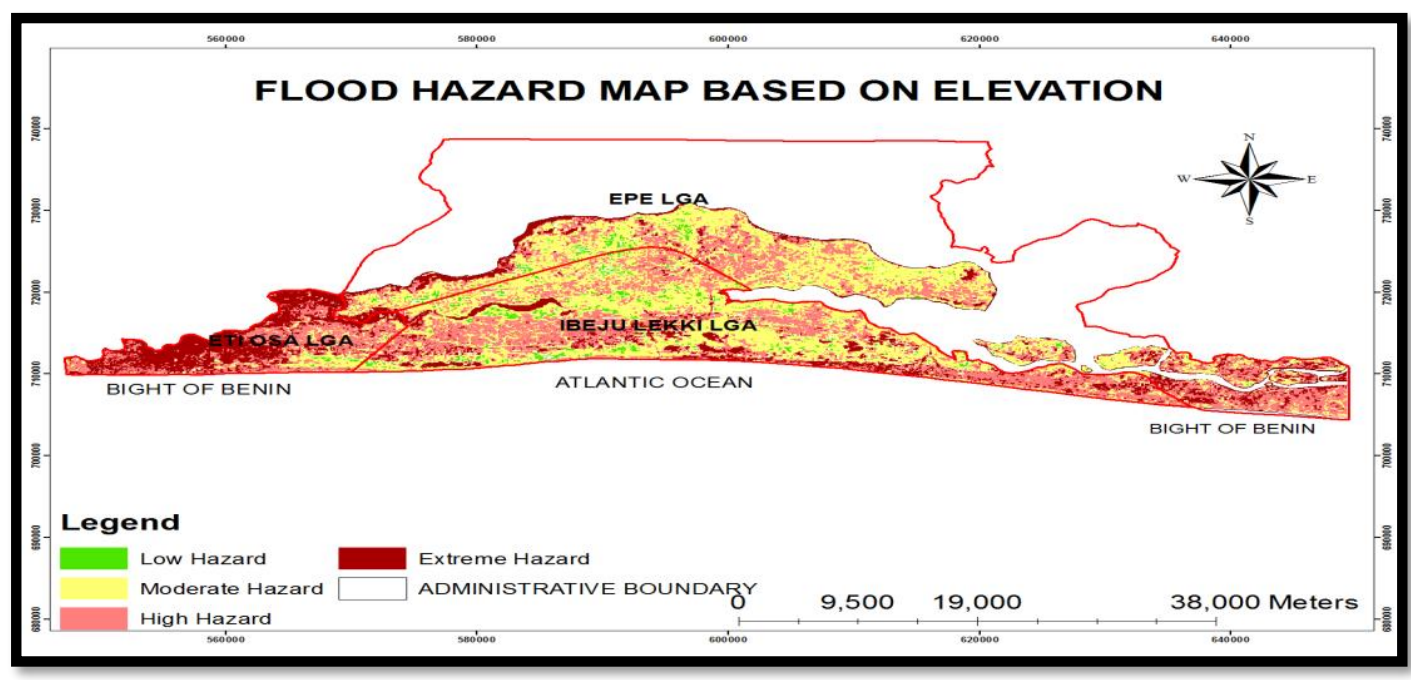

Figure 3.4: Flood hazard potential for both pluvial \& marine flood based on planar water levels/elevation $(0.51-2 \mathrm{~m}=$ extreme hazard $)$.

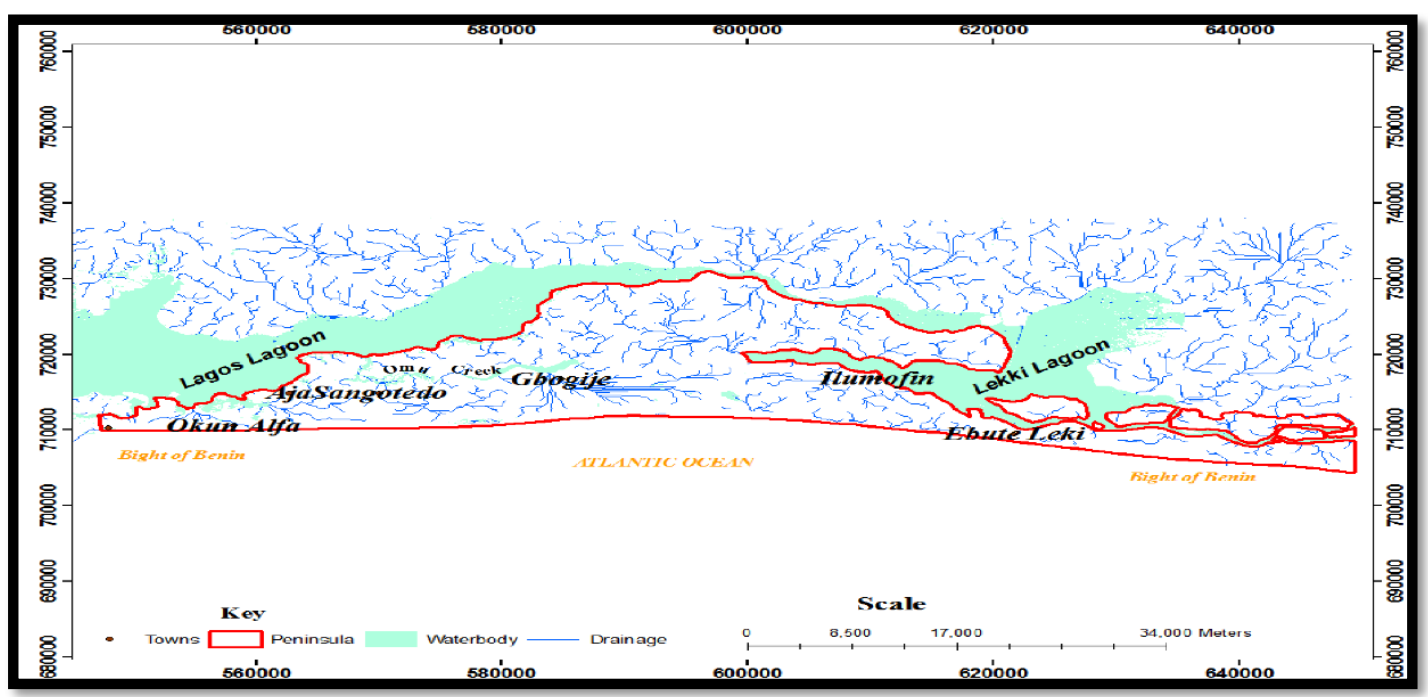

Figure.3.5: Surface drainage network and drainage basins or lack of in the Peninsula (Generated from SRTM DEM).

Table 3. 2 Points of maximum erosion in Etiosa LGA (Derived from Google imagery of $2001 \& 2013$ ).

\begin{tabular}{lccc}
\multicolumn{4}{c}{ POINTS OF EROSION MEASUREMENTS (All in Eti-Osa LGA) } \\
\hline \multicolumn{1}{c}{ S/N } & Length (m) & $\begin{array}{c}\text { Meridian }\left({ }^{\circ} \mathbf{E}\right) \\
\text { along segment }\end{array}$ & \begin{tabular}{c} 
Annual erosion rate $(\mathbf{m})$ \\
\hline 1
\end{tabular} \\
& 273 & 3.4308 & 22.75 \\
2 & 197 & 3.4336 & 16.42 \\
3 & 166 & 3.4382 & 13.83 \\
4 & 124 & 3.4427 & 10.33 \\
5 & 110 & 3.4472 & 9.17 \\
6 & 105 & 3.4518 & 8.75 \\
7 & 99 & 3.4563 & 8.25 \\
8 & 95 & 3.4607 & 7.92 \\
9 & 94 & 3.4651 & 7.83 \\
10 & 65 & 3.4698 & 5.42 \\
11 & 82 & 3.4741 & 6.83 \\
12 & 66 & 3.4789 & 5.50 \\
\hline
\end{tabular}




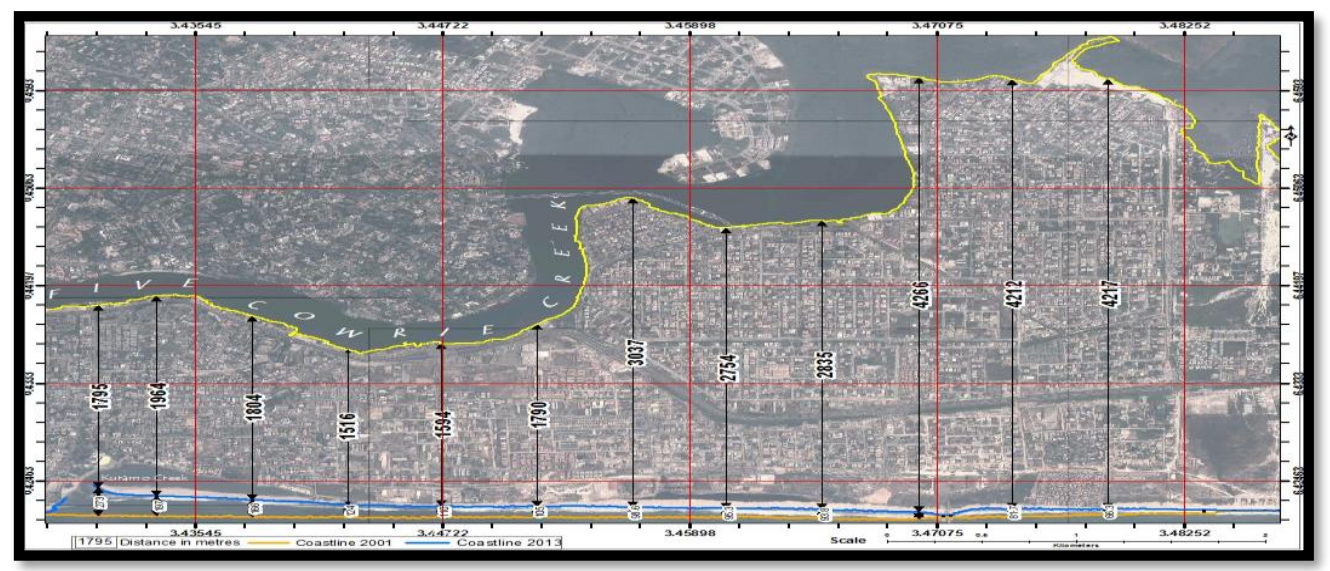

Fig. 3.6 Areas of maximum erosion in Etiosa LGA (Derived from Google imagery 2001 \& 2013).
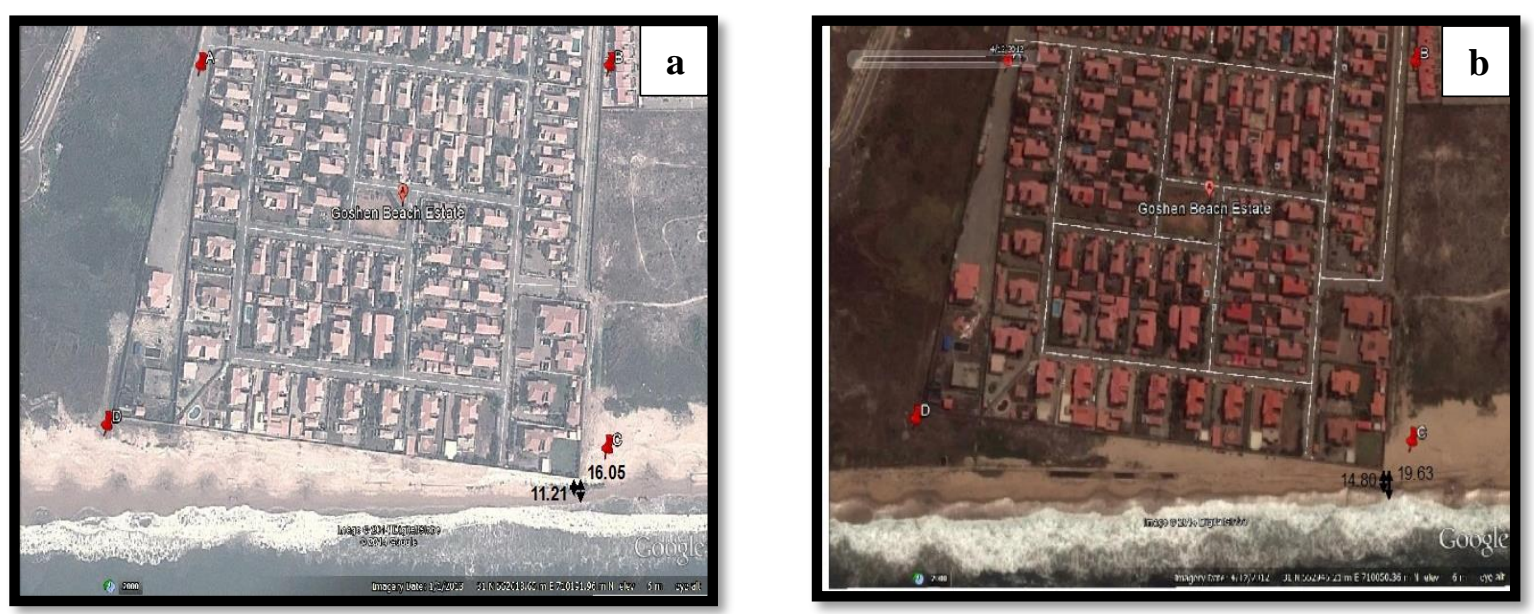

Plate 3.1a, b. Goshen Estate in 2012 and 2013 showing distances of the fence from the coastline. Note the beach configuration before the construction of groins; a. Goshen Estate in 2012 showing distance of fence from the coastline $-19.63 \mathrm{~m} \&$ wet/dry line - 14.80m; b. in 2013 showing distance of fence from coastline $-16.05 \mathrm{~m} \&$ wet/dry line $-11.21 \mathrm{~m}$ (after erosion/ocean surge of July 2012 (Imagery source: Google Earth, 2012 \& 2013).

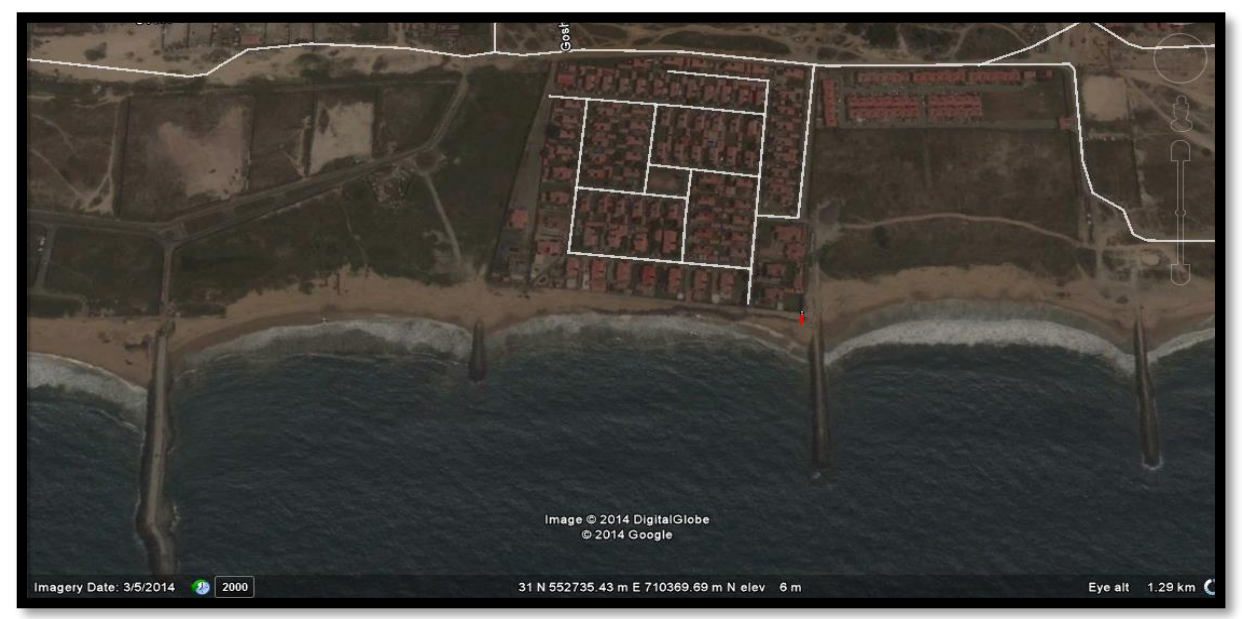

Plate 3.2. Google imagery of 5/3/2014 showing newly constructed groins around Goshen Estate and new u-shaped erosion/accretion between the groins. The new groins are apparent confirmation of extant serious erosion.

The results of coastal erosion risk evaluation show that the minimum land area potentially eroded in Eti-Osa LGA by the year 2023 is 36ha, 64ha in 2033 and 94ha in 2043 while the maximum in 2043 is 408ha if the erosion remains unchecked and at these rates. Also, the minimum to maximum potential economic losses in building and road assets in this area range from N1.16billion in 2023 to N139.42 billion in 2043 in today's values.

\section{Discussion and Recommendations}


The transect of island width on Meridian 3.44270E in EtiOsa LGA showed a reduction of $0.12 \mathrm{~km}$ between 2001 and 2013 , occasioned by shoreline erosion. As a measure of life expectancy of the island, this is indicative of the space left before the island is severed by erosive forces if the problem is left unattended to. The spatial distribution of heights in the three council areas amply confirms the Peninsula as generally low lying. The absence of discernible direction of slope, definitive watersheds and drainage basins lends credence to this low-lying nature. These results comparatively reveal that Eti-Osa LGA, which is the most developed currently is the lowest - lying of the councils in the Peninsula with heights of $0.5-3 \mathrm{~m}$ being dominant. The flood hazard map based on 'bathtubfill' method/elevation shows that most of the area of extreme flood hazard potential $(0.51-2 \mathrm{~m})$ is in Eti-Osa LGA. This means that about $50 \%$ of the council is $2 \mathrm{~m}$ and below, hence flood waters of slightly above $2 \mathrm{~m}$ (above m.s.l) will likely inundate $50 \%$ of the council. Epe LGA is the council with the highest percentage of areas of the height of 3 - 4m followed closely by Ibeju - Lekki LGA. These translate into areas of potentially less flood hazard than in Eti-Osa LGA. Contrary to the elevation range of 5 - $15 \mathrm{~m}$ used in the drainage master plan in the new Lekki Infrastructure Master Plan (Dar al - Handasah, 2009), there is hardly any significant area in the Peninsula above $5 \mathrm{~m}$ height. The sand filling of Lekki Phase 1 and the subsequent piecemeal sand filling of other areas like Lekki-Epe Expressway disorganised the minimal drainage courses which existed previously in Eti-Osa (Dar al- Handasah, 2009). As such, Jakande Estate, Lekki, excised villages of Maiyegun, Aro, Igbo Efon and Okun Alfa, for example, are severely inundated from pluvial flooding as they are generally lying lower than the Expressway and advisably cannot drain to the Atlantic Ocean. It is conceivable that in time, the state may undertake to buy out the owners of these places to properly raise the levels well above the expressway to drain to the lagoons. Low elevation with hardly any discernible direction of slope, high water table and a severe lack of drainage heads make comprehensive surface drainage and sewer system for the Peninsula herculean ventures. This is what compelled the recommendation of a cluster of eight (8) sewage treatment plants for the Peninsula with requisite lift stations to discharge effluent to the lagoons (Dar al - Handasah, 2009). Among the requirements for recommending flood resilient levels for new development given low elevation are the Base Flood Elevation (BFE) and Design Flood Elevation (DFE). Based on the elevation analysis and flooding evaluation, a BFE of $3.1 \mathrm{~m}$ above m.s.l and a DFE of $3.7 \mathrm{~m}$ above m.s.l for new developments are suggested. For flood resilience and to save lives, new buildings should be elevated off the ground at least $3 \mathrm{~m}$ above the suggested DFE.

The evaluation of beach recession shows that erosion and beach recession have clearly shifted eastwards to areas of the Peninsula which were reported in Ibe (1988) to be experiencing accretion at the time. The effect is that at the average and maximum rates of erosion occurring in this vicinity, erosion at the narrowest segment of $1.52 \mathrm{~km}$ leaves this area with a potential lifespan of 66 - 142 years from 2013 if the erosion remains unchecked. The evaluation of risks from coastal erosion underlines the elevated risks Goshen Estate, buildings and road infrastructure in the area are exposed to from both ocean surge and continued erosion and helps to illuminate the need for proactive planning for emergency towards the safety of residents of the area. It also illuminates the potential economic losses to property owners in this vicinity as well as potential losses to the construction industry generally for the loss of beach lands here which have been earmarked for recreational development in the current infrastructure master plan (Dar al - Handasah, 2009). Further, it draws attention to the potential loss of livelihoods of beach recreation operators in this area as the beaches are among the first line area to be potentially eroded. The potential risks outlined should form part of the wake-up call for planning for emergencies in this area. Planning for emergencies in the area is necessary because as determined from literature in the course of this study, regardless of the coastal protection measures being undertaken or contemplated, hard engineering protection measures quite often shifts the erosion problem down drift from its location. Besides, coastal erosion as part of barrier island's physical processes is inevitable regardless of measures undertaken.

\section{New challenges}

As is indicated above, some groins were shown to have been constructed on the coastline around Goshen Estate by March 2013. On Friday, June 3, 2016, The Guardian Newspaper (www.guardian.ng) ran an editorial based on the previous briefing by the Lagos State Commissioner for Waterfront Infrastructure Development titled 'Taming Ocean Surge in Lagos'. This was to the effect that the state authorities had earmarked N36billion for the construction of 18 groins at $40 \mathrm{~m}$ intervals between Goshen Estate and Alpha Beach to the east at the cost of N2billion per groin. To be certain on the actual situation on the ground, a check on Google Earth imagery of 11/5/2016 revealed sixteen (16) groins spaced about $400 \mathrm{~m}$ have been constructed from Goshen Estate past Maiyegun Beach towards Alpha Beach (Plate 5.1).

The most compelling question on this huge investment is will groins tame ocean surge and erosion on the Peninsula? Evidence from literature makes this doubtful. In their natural states, beaches and barrier islands are resilient landforms having been made to absorb and dissipate the energy of breaking ocean waves by shifting and changing in shape (eroding and accreting) in response to ocean forces and sea level changes (Watson and Adams, 2011). Where development intervenes in this process as in Lekki Peninsula, these processes transform into hazards requiring solutions to protect the coastline. Among the common structural measures or 'hard 


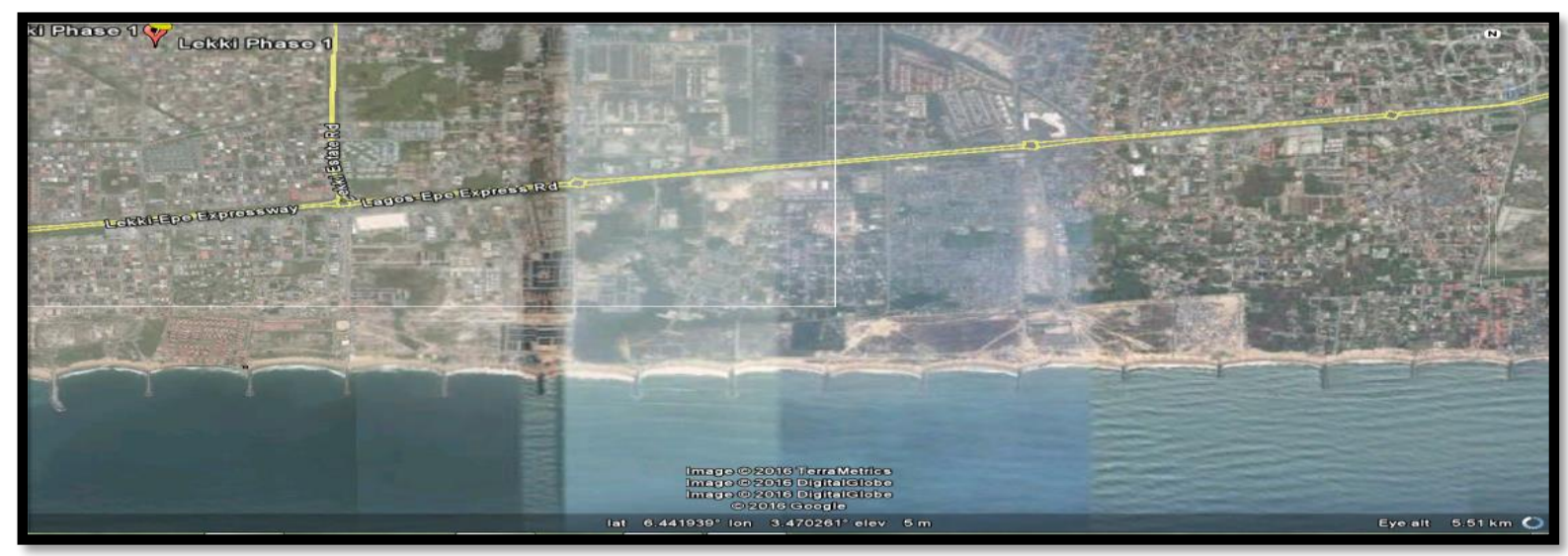

Plate 5.1 Imagery of 16 groins spaced about 400m from Goshen Estate towards Alpha beach as at May 11, 2016 (source: Google Earth, 2016).

Engineering structures' are groins, seawalls and bulkheads, revetments, jetties, geotextile containers and sometimes, breakwaters. Groins are rock structures built perpendicular to the shore to intercept the littoral migration of beach sand. It has been observed that solid structures often reflect incoming waves sharply causing greater turbulence and increased erosion downdrift from their location (Watson \& Adams, 2011).

Under these circumstances, to gain a broader insight, it became instructive to illustrate an example of a similar situation on developed barriers of Long Island, New York, USA. It is expected that an enduring solution can be found and implemented in this context if possible. Where have groins then abated erosion? Maybe this can happen on Lagos coastline but not on the coastline of the barriers of Long Island, New York. As reported in Tanski (2007) and Coch (2015), Long Island's Atlantic shoreline in New York is occupied by a series of dynamic barrier islands,

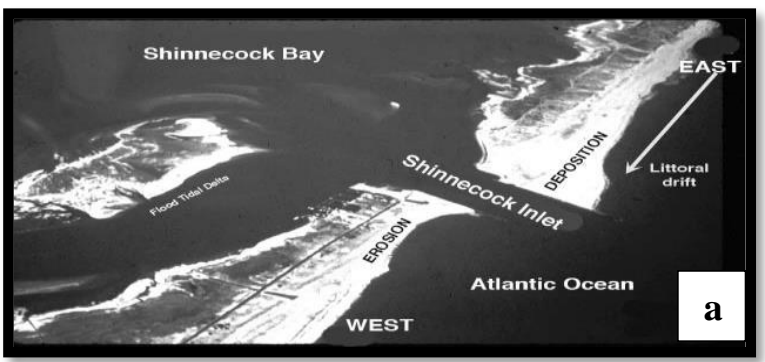

some heavily developed while some are natural resource areas. After the 1938 hurricane, coastal engineering structures including groins, sea walls and jetties were viewed as means to increase beach width to minimise storm damage and to stabilise storm-cut inlets on Long Island (Coch, 2015; US Beach Erosion Board, 1946). Jetties were thus built to stabilise inlets such as Shinnecock Inlet in Southampton (Plate 5.2) and others. These jetties reduced the natural westward longshore sand movement along the south shore of Long Island resulting in sand accumulation on the up-drift or east side while the beach on the down-drift or west side of the inlet was severely eroded. The building of many groins to trap sand moving along the shore to widen local beaches and as storm protection measures, Coch (2015) concluded resulted in severe beach erosion of the western end of Long Island (Plates $5.3 \& 5.4$ ).

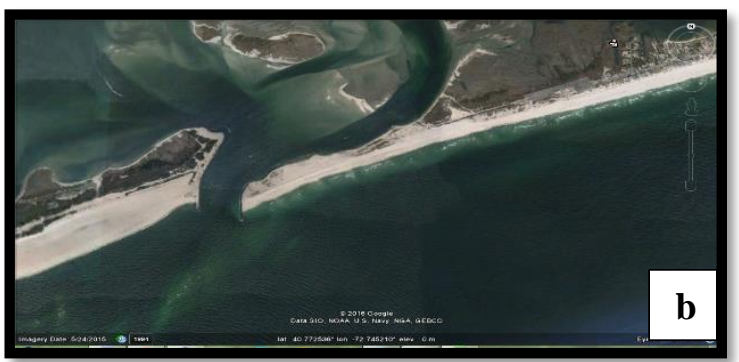

Plate 5.2: Erosion resulting from stabilisation of Shinnecock Inlet in Southampton, Long Island, New York. The up-drift side of the inlet (right) is accumulating sand against the jetty. The lack of sand supply on the down-drift side of the inlet causes erosion (source: Coch, N.K., 2015 \& Google Earth, 2015; imagery date - 24-5-2015).

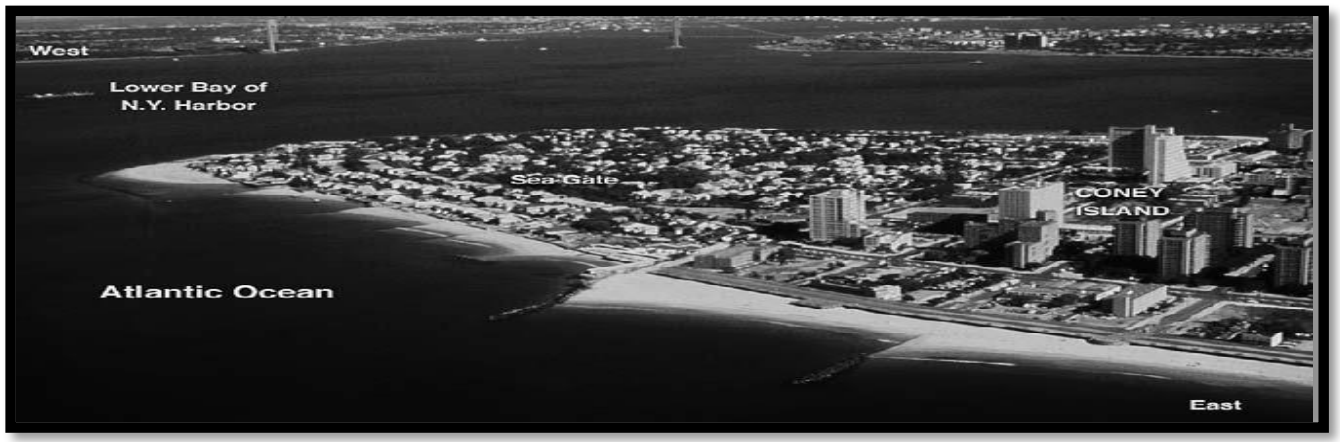

Plate 5.3 Aerial view of Coney Island at the western end of Long Island, NY. Relatively little sand manages to get here from its source in eastern Long Island. (Source: Coch, N.K., 2015). 


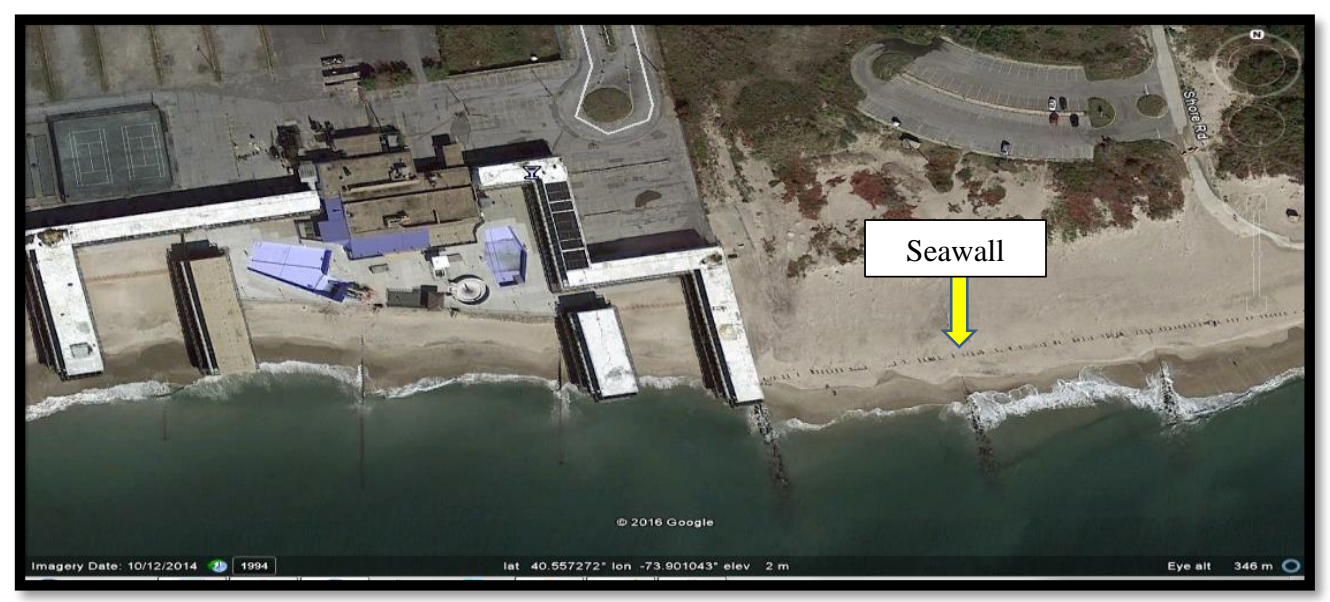

Plate 5.4 Even with groins, seawalls \& palpable deposition, erosion is alive on Long Island barriers and the Cabana complex was at risk on 12-10-2014. Imagery captured on 12-10-2016. (source: Google Earth, 2016).

Clearly, if groins have failed to abate coastal erosion over the years on Long Island, New York and elsewhere (Escudero, Silva \& Mendoza, 2014; Gomes \& da Silva, 2014), the prospect of it doing so on Lekki Peninsula is seriously in doubt. In this regard, the pattern of effects of groins on Long Island, New York is beginning to similarly manifest on Lekki Peninsula shoreline. For instance, in about $2^{1 / 2}$ years since the construction around Goshen Estate, the $\mathrm{u}$-shaped shoreline formation characteristic of groin formation on imageries and aerial photos has emerged on the previously almost linear shoreline of the Peninsula.

Furthermore, the imagery of 11-5-2016 still shows the back fence of this Estate as still on elevating risk of being washed away with almost no noticeable beach accretion. While these may be the case, non-structural or 'soft' coastal and barrier island protection measures are recommended as part of a suite of solutions instead of a one-off approach with groins. These actions include among others dune restoration and beach nourishment, vegetative shore protection, coastal wetland restoration/conservation and substantial setback distances from the shoreline. Others include hybrid stabilisation techniques involving nourishment, vegetative techniques involving the planting of dune grasses and other native shoreline species and geotextile measures are also employed (Watson and Adams, 2011). Although beach nourishment is expensive and failed severally in Victoria Island in the past, evidence in literature shows that many developed countries including the Netherlands (Bakker et al., 2012) have robust beach replenishment programs in shoring up the beach berm and dunes. Finally, despite the suggested measures and any other being implemented for the resilience of development in the Peninsula, it needs to be re-emphasized that low elevation, coastal erosion,

\section{References}

Abegunde, M.A.A. (1988). Shoreline Erosion and Land Use Management on the Active Sand Barrier Beaches around Lagos: A New Focus in Environmental Management in Sada, P.O. \& F.O. Odemerho. (eds). flooding (pluvial and marine) are unchangeable natural processes of this barrier island and others and thus their life cycle. Protection measures can only buy time but not stop their mobility. With sea level rise as predicted, these processes are expected to exacerbate. Part of our overall resilience strategy should, therefore, be the option of 'retreat' when possible.

\section{Conclusion}

As a basis for understanding the sister barriers on the Lagos coastline, this study has shown a low budget integration of free/online high resolution imagery data, SRTM DEM and GIS techniques to assess geo-indicators (or proxies of coastal processes) and evaluate some environmental risks to urban development on Lekki Peninsula from hazards inherent in its physical processes. It has also demonstrated simple, repeatable, approaches to pre-disaster coastal risk assessment. Findings have underscored the area as narrow in some locations, lowlying, prone to pluvial flooding as a result and afflicted in some parts by rapid shoreline erosion. These have also helped to establish that some of the risks to urban development in the Peninsula are those tied to its dynamic characteristics as a barrier island. Appropriate suggestions for the resilience of new developments have been made. Furthermore, the study provides actionable spatial information which can be part of the decision-support tool in evaluating urban development on the Peninsula and sister Lagos coastline barriers. An area for further inquiry is a continuous evaluation of the physical effects, gains/losses on the coastline from the groins so far emplaced on the Peninsula.

Environmental Issues and Management in Nigerian Development. Evans Brothers, Ibadan 231-238.

Adepelumi, A.A. (2008). Delineation of Saltwater intrusion into the freshwater aquifer of Lekki Peninsula, Lagos, Nigeria. The 3rd International Conference on Water Resources and Arid Environments (2008) and the 
1st Arab Water Forum. Available from: www.faculty.ksu.edu.sa.pdf.

Asangwe, C.K. (2006). The Douala Coastal Lagoon Complex. Cameroon: Environmental Issues. 14p. Retrieved from: www.fig.net/pub/figpub/pub36/chapters/chapter_9.pdf.

Awosika, L. Adekoya, E.A., Adekanmbi, M. A., Dublin - Green, C.O., Folorunsho, R. and Jim- Saiki L. (2000). Study of Main drainage channels of Victoria and Ikoyi Islands in Lagos, Nigeria and their Responses to Tidal and Sea Level Changes. UNESCO - CSI: Environment and Development in Coastal Regions and Small Islands.108p. Available at: http://www.unesco.org/csi/act/lagos/drains2.htm.

Awosika, L.F., French, G.T., Nicholls, R.J. and Ibe, C.E. (1993a) Impacts of Sea Level Rise on Nigeria: Proceedings of IPCC Symposium: The Rising Challenges of the Sea. Margarita, Venezuela. March 14-19, 1992.

Bakker, M.A.J., Van Heteren, S., Vonho Gen, L.M.; Van Der Spek, A.J.F., and Van Der valk, L. (2012). Recent coastal dune development: effects of sand nourishments. Journal of Coastal Research, 28(3):587601. doi:10.2112/JCOASTRES-D-11-00097.1.

Bates, P. D., Dawson, R. J., Hall, J. W., Horritt, M. S., Nicholls, R. J., Wicks, J. and Hassan, M. A. (2005). Simplified Two-dimensional Numerical Modelling of Coastal Flooding and Example Applications. Coastal Engineering, 52: 793 - 810.

Bush, D, M., Neal, W. J., Norma J. Longo, Linderman, K. C., Pilkey, D. F., Esteres, L. S., Congleton, J. D. and Pilkey, O. H. (2004). Living with Florida's Atlantic Beaches: Coastal Hazards from Amelia Island to Key West. Duke University Press. 360p.

Bush, D.M., Neal, W. J., Young, R. S. and Pilkey, O. H. (1999)). Utilization of geo-indicators for rapid assessment of coastal hazard risk and mitigation. Ocean and Coastal Management, 42: 647-670. doi:10.1016/S0964 - 5691 (99)00027-7.

Coch, N.K., (2015). Unique vulnerability of the New York-New Jersey Metropolitan Area to hurricane destruction. Journal of Coastal Research, 31(1), 196-212. DOI:10.2112/JCOASTRES-D-13-00183.1

Dar al-Handasah (Shair and Partners), (2009). Comprehensive Infrastructure Master Plan for Lekki Sub - Region, Lagos City - Nigeria. Final Master Plan Report. Ministry of Physical Planning \& Urban Development, Lagos State, Oct. 2009. 182p.

Escudero, M.; Silva, R., and Mendoza, E. (2014). Beach erosion driven by natural and human activity at Isla del Carmen Barrier Island, Mexico. In: Silva, R., and Strusińska-Correia, A. (eds.), Coastal Erosion and Management along Developing Coasts: Selected Cases. Journal of Coastal Research, Special Issue, No.71, 62-74. ISSN 0749-0208. DOI: 10.2112/SI71-008.1

Feagin, R. A., Smith, W.K., Psuty, N. P., Young, D. R., Martinez, M.L., Carter, G.A., Lucas, K.L., Gilbeaut, J.C., Gemma, J.N. and R. E. Koske (2010). Barrier Islands: Coupling Anthropogenic Stability with Ecological Sustainability. Journal of Coastal Research, 26(6): 987992. DOI: $10.2112 / 09-1185.1$

Gomes, G. and Silva, A.C. (2014). Coastal erosion case at Candeias Beach (NE-Brazil). In: Silva, R., and Strusińska-Correia, A. (eds.), Coastal Erosion and
Management along Developing Coasts: Selected Cases. Journal of Coastal Research, Special Issue, No. 71, 30-40., ISSN 0749-0208. DOI: 10.2112/SI71-004.1.

Ibe, A. C. (1988). Coastline Erosion in Nigeria. Ibadan University Press. 217p.

Jack, J. (2003). Barrier Islands and Coastal communities. Environmental Science: Regional Updates, 5p. Retrieved from: www.prenhall.com/esm/app/nebel/html/.../update17.htm 1.

Jensen, J.R. (2007). Remote Sensing of the Environment: An Earth Resource Perspective 2nd ed. Pearson Prentice Hall, Upper Saddle River, N.J. 07458. 592 p.

Lagos State Government. (1980). Lekki Peninsula Development Scheme Report. 111p.

Mcharg, Ian L.(1971). Design with Nature. John Wiley and Sons, Inc. New York. 198p.

Nwilo, P.C. (1997). Managing the Impacts of Storm Surges on Victoria Island, Lagos, Nigeria In Destructive water: Water- Caused Natural Disasters, their Abatement and Control. Proceedings of the conference held at Anaheim, California, June 1996. IAHS Publ. no.239, 1997: 325 - 330.

Otegbulu, Austin, (ed.) (2013). Natural Resource Valuation and Damage Assessment in Nigeria: A Case Study of the Niger Delta. Report of the MacArthur Foundation Funded Project. University Press Plc. 111p.

Population Reference Bureau - PRB. (2003). Ripple Effects: Population and Coastal Regions, PRB, September 2003.

Poulter, B., and P.N. Halpin. (2008). Raster Modelling of Coastal Flooding from Sea-Level Rise. International Journal of Geographical Information Science, 22(2): 167182.

Stutz, M.L. and Pilkey, O.H. (2011). Open-Ocean Barrier Islands: Global Influence of Climatic, Oceanographic and Depositional Settings. Journal of Coastal Research, 27(2): 207 - 222. DOI: 10.2112/091190.1.

Stutz, M.L. and Pilkey, O.H. (2005). The Relative Influence of Humans on Barrier Islands: Humans versus Geomorphology in Ehlen, J., Haneberg, W.C., and Larson, R. A. (eds). Humans as Geologic Agents, Boulder, Colorado. Geological Society of America Reviews in Engineering Geology v. XVI: 137 - 147.

Tanski, J. (2007). Long Island's Dynamic South Shore - A Primer on the Forces and Trends Shaping Our Coast.

New York Sea Grant. 27p. Retrieved on 29-12-2016 from

www.seagrant.sunysb.edu/cprocesses/pdf/LIDynamicSo uthshore.pdf.

Taylor, E. B. (2014). Increasing Resilience of Urban Development on Texas Barrier Islands. An unpublished PhD Dissertation, Texas A \& M University, Corpus Christi, Texas, USA. May 2014. 165p.

U.S. Army Beach Erosion Board, (1946). Beach Erosion Study of Long Island (South Shore), New York. Washington, DC: War Department, 25p.

Western Carolina University (WCU - 2005). Coastal Hazards. Costal Hazards Information Clearing House at WCU. Chapters 1-10. Retrieved from: http://wwww.wcu.edu/coastalhazards/libros/index.html. 
Van-de Sande, B. (2012). Sensitivity of Coastal Flood Risk Assessments to Digital Elevation Models. Water 2012, 4, 568 - 579; doi:10.3390/w4030568.
Zhang, K. and Leatherman, S. (2011). Barrier Island Population along the U.S. Atlantic and Gulf Coasts. Journal of Coastal Research, 27(2), 356-363. ISSN 0749-0208. DOI:10.2112/JCOASTRES-D-1000126.1 